\title{
Influence of transplanting dates and population densities on the growth and yield of onion
}

\author{
Muhammad Ali ${ }^{1,2 *}$, Abdur Rab ${ }^{2}$, Jawad $\mathrm{Ali}^{2}$, Husain Ahmad ${ }^{1,2}$, \\ Sikandar Hayat ${ }^{1,2}$, Kashif Wali ${ }^{2}$, Anwar Rashid ${ }^{2}$, Waqas Ahmad ${ }^{1,3}$ \\ and Haji Muhammad ${ }^{2}$ \\ 1. College of Horticulture, Northwest A \& F University, Yangling, Shaanxi, China 712100. \\ 2. Department of Horticulture, The University of Agriculture Peshawar, Pakistan. \\ 3. College of Agronomy and Biotechnology, China Agricultural University, Beijing, P. R. China \\ *Corresponding author's email: maliaup4@gmail.com
}

Citation

Muhammad Ali, Abdur Rab, Jawad Ali, Husain Ahmad, Sikandar Hayat, Kashif Wali, Anwar Rashid, Waqas Ahmad and Haji Muhammad. Influence of transplanting dates and population densities on the growth and yield of onion. Pure and Applied Biology. Vol. 5, Issue 2, 2016, pp345-354. http://dx.doi.org/10.19045/bspab.2016.50045

\begin{tabular}{llll}
\hline \hline Received: 05/02/2016 & Revised: 22/03/2016 & Accepted: 03/04/2016 & Online First: 18/04/2016 \\
\hline \hline
\end{tabular}

Abstract

A field experiment was carried out to study the "Influence of transplanting dates and population densities on the growth and yield of onion" was carried out at Dargai with collaboration of Agriculture Extension Department, Dargai Malakand Division, Pakistan. The experiment was designed as Randomizes Complete Block Design (RCBD) as Split plot arrangement having two factors, transplanting dates and row spacing. Transplanting dates $\left(15^{\text {th }}\right.$ December, $31^{\text {st }}$ December and $15^{\text {th }}$ January) were in the main plots while row spacing $(15,20,25$ and $30 \mathrm{~cm})$ were in sub plots replicated three times. Recommended dose of NPK (120: 90: 60) $\mathrm{kg} \mathrm{ha}^{-1}$ were applied. Swat-I variety of onion was grown. The data on number of leaves plant ${ }^{-1}$, plant height $(\mathrm{cm})$, leaf width $(\mathrm{cm})$, bulb diameter $(\mathrm{cm})$, average bulb weight $(\mathrm{g})$, number of bubs $\mathrm{kg}^{-1}$ and total yield $\mathrm{t}$ $\mathrm{ha}^{-1}$ were recorded. Significant variations were recorded for transplanting dates and different row spacing for all the parameters studied. The mean data showed that plants with transplanting date of $15^{\text {th }}$ December resulted best in all the parameters, i.e. maximum number of leaves plant ${ }^{-1}$ (9.94), plant height $(47.58 \mathrm{~cm})$, leaf width $(1.42 \mathrm{~cm})$, bulb diameter $(6.06 \mathrm{~cm})$, average bulb weight $(79.70 \mathrm{~g})$ and yield $\left(28.64 \mathrm{t} \mathrm{ha}^{-1}\right)$. Among row spacing, the maximum row spacing (30 $\mathrm{cm})$ produced the maximum number of leaves plant $^{-1}(10.18)$, plant height $(47.00 \mathrm{~cm})$, leaf width $(1.41 \mathrm{~cm})$, bulb diameter $(6.58 \mathrm{~cm})$ and average bulb weight $(91.59 \mathrm{~g})$. Maximum number of bulbs $\left(18.22 \mathrm{~kg}^{-1}\right)$ was recorded at plants with row spacing of $(15 \mathrm{~cm})$. However, plants with row spacing $(20 \mathrm{~cm})$ produced a maximum yield $\left(29.29 \mathrm{t} \mathrm{ha}^{-1}\right)$. It is concluded from the experimental study that best yield was observed at row spacing $20 \mathrm{~cm}$ with a transplanting date of $15^{\text {th }}$ December, therefore recommended for onion production under the agriculture climatic condition of Malakand.

Key words: Onion (Allium cepa L.); Transplanting dates; Row spacing; Number of leaves plant ${ }^{-}$

${ }^{1}$; Plant height 


\section{Introduction}

Onion botanically called as Allium cepa (Latin), is a bulbous crop belongs to Amaryllidaceae family. It is commercially grown in different countries including Pakistan. It is used in green as well as in bulb stages [1]. Genus Allium has about 300 species and many of them have onion flavor and smell [2].

Onion is a monocotyledonous, crosspollinated, biennial, cool-season, and comparatively shallow rooted [3]. Its bulb has a sulphur-bearing compound, which is volatile oil (allyl propyl disulphide) and pungent. Onion stores food as starches, sugar or oils. In the first year, an onion plant stores sugars in the bulb; this is actually swollen leaf base. In the second years, this sugar is used up as the plant grows and flowers. When the sugar of onion is strongly heated it turns the onion brown [4].

Agronomic practices greatly influence onion production among which, planting time is one of the important factor that greatly affect the growth and yield of onion [5]. Early planting gives the longest growth cycle and thus the highest yield $\left(16^{\text {th }}\right.$ November) $[6,7]$. On the other hand, high temperature faced by late planting results in early maturity and thus lower yield. Optimun time of planting gives favourable conditions for maximum vegetative growth and it is not obtained with the delayed planting $[8,9]$.

For the production of onion spacing is very important factor. It directly influences the quality and production of onion. Proper spacing of onion crop may be a significant factor for economic and high bulb yield. Khan et al. [10] who stated that, the wider spacing $(20 \mathrm{x} 10 \mathrm{~cm})$ gave maximum number of leaves, leaf length, plant height, bulb length, diameter and weight of onion. As plant population increases, onion bulb yield also increases because the leaf canopy intercepts a higher percentage of light [11]. Plant population needs to be optimized. The optimum use of spacing or plant population has dual advantages [12]. It avoids strong competition between plants for growth factors such as nutrient, water and light. In addition, optimum plant population enables efficient use of available cropland without wastage. So it is a great time to respond these problems.

\section{Materials and methods}

An experiment entitled "The influence of transplanting dates and population densities on the growth and yield of onion" was carried out at Dargai with collaboration of Agriculture Extension Department, Dargai Malakand Division. The experiment was designed as Randomizes Complete Block Design (RCBD) having a split plot arrangement. Two factors viz, transplanting dates and row spacing. Swat-I variety of onion was grown.

Soil was ploughed thoroughly and leveled. Well-decomposed farmyard manure was mixed with the soil. Swat-I variety of onion was used. Different row spacing was given in the field. All other practices were done usually. Recommended dose of NPK (120: 90: 60) $\mathrm{kg} \mathrm{ha}^{-1}$ were applied. In this experiment, Urea was source of nitrogen having $46 \%$ of nitrogen which was applied in two split doses. Half dose was applied at the time of transplantation and half after one month of transplantation. Sulphate of potash was source of potash, having $50 \%$ of potash while single super phosphate was source of phosphorous, having $18 \%$ of phosphorous. From experimental field, soil samples were taken randomly from different places at 15 to $30 \mathrm{~cm}$ depth before other fertilizer applications were analyzed. Below the given figures 1 and 2 showed the average rainfall and temperature of that experimental year (2011-2012) of dargai area. 
Apparently equal height and vigor seedling was transplanted on December $15^{\text {th }}$, December $31^{\text {st }}$ and January $15^{\text {th }}$ in the field with the row spacing of $15,20,25$ and 30 $\mathrm{cm}$. The seedling was immediately irrigated. Cultural practices i.e. hoeing, weeding, etc. was performed on a regular basis throughout the experiment.

\section{Statistical analysis}

The data of different parameters were Analysis for Variance (ANOVA) technique to see the differences between different treatments and their interactions. In cases where differences were found significant, the means were further assessed for differences using Least Significant Difference (LSD) test. Statistical computer software, MSTATC (Michigan state university, USA), was applied for computing both ANOVA and LSD. (Steel and Torrie, 1980).

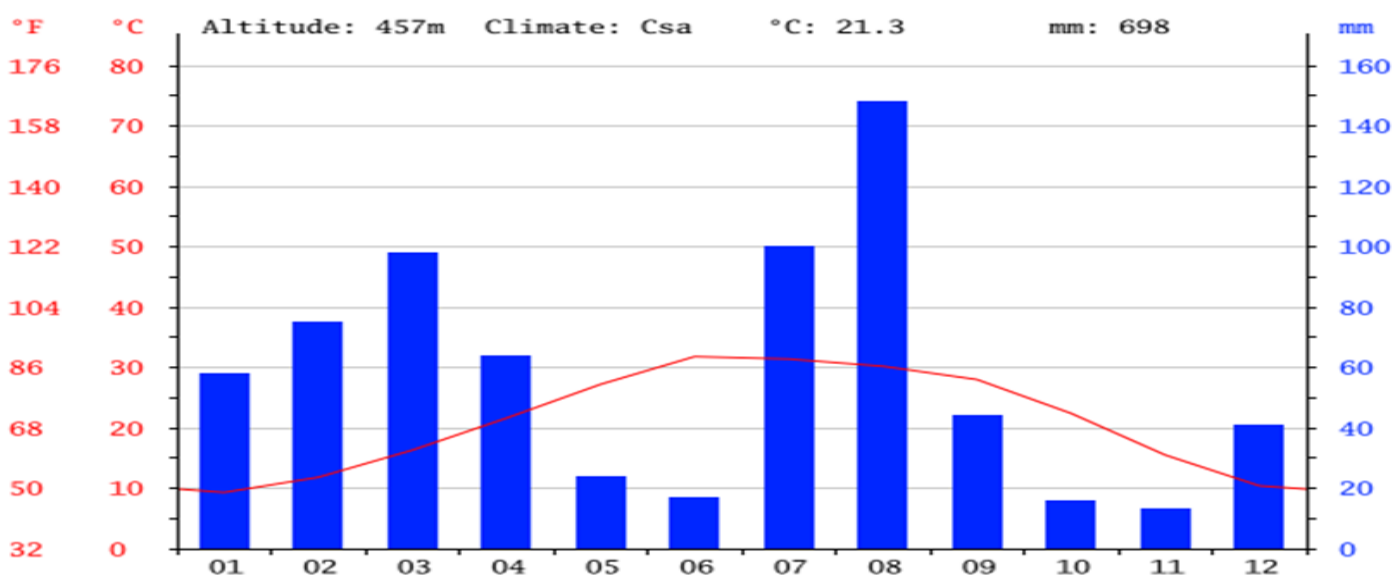

Figure 1. Rainfall graph. The least amount of rainfall occurs in November. The average in this month is $13 \mathbf{~ m m}$. The greatest amount of precipitation occurs in August, with an average of $148 \mathrm{~mm}$

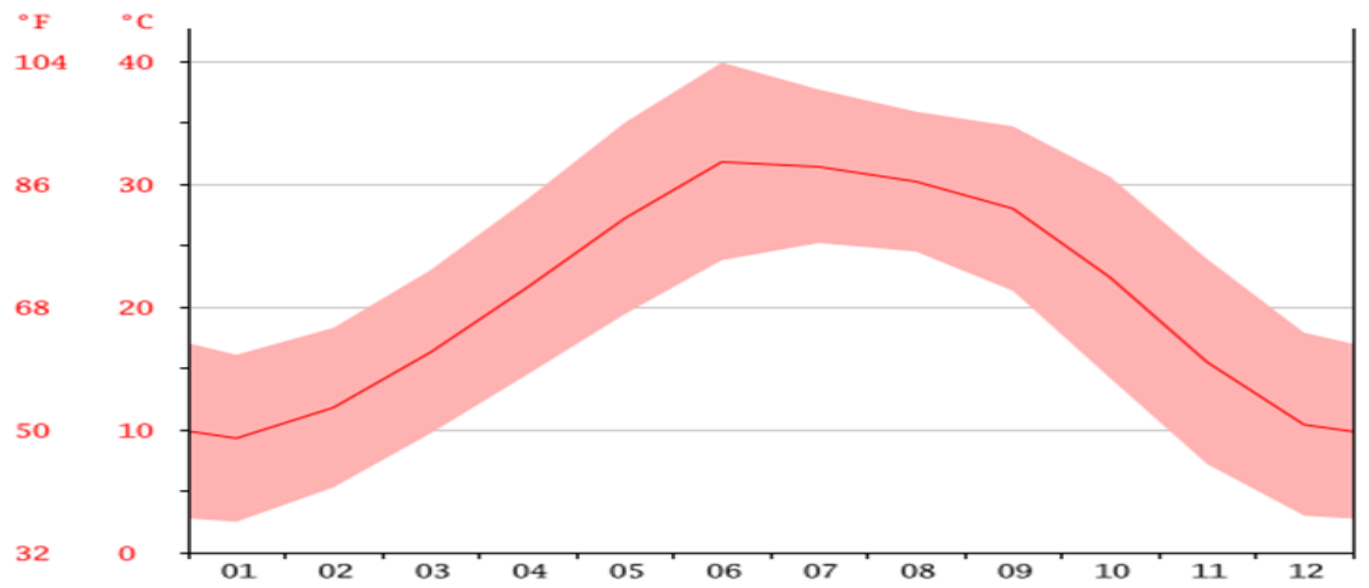

Figure 2. Temperature graph. June is the warmest month of the year. The temperature in June averages $32.1{ }^{\circ} \mathrm{C}$. In January, the average temperature is $9.5^{\circ} \mathrm{C}$. It is the lowest average temperature of the whole year 


\section{Results and discussion}

The aim of this study was to find out the influence of transplanting dates and different row spacing on the growth and yield of Onion. Onion was sown on $\left(28^{\text {th }}\right.$ Oct, $11^{\text {th }}$ Nov, and $25^{\text {th }}$ Nov) and transplanted on $15^{\text {th }}$ Dec, $31^{\text {st }}$ Dec and $15^{\text {th }}$ Jan respectively, with different row spacing of $15,20,25$ and $30 \mathrm{~cm}$. The results of the recorded data are discussed as under.

\section{Number of leaves plant $^{-1}$}

The results relating to the number of leaves of onion showed significant variations for the transplanting dates, row spacing and their interactions (Table 1). In case of transplanting dates, significantly maximum number of leaves (9.94) were recorded in $15^{\text {th }}$ December transplantation, which was at par with $31^{\text {st }}$ December transplantation (9.16) while the lowest number of leaves (6.80) was obtained from the seedlings transplanted on $15^{\text {th }}$ January. Seedlings that were transplanted on $15^{\text {th }}$ December resulted in maximum number of leaves. This may be due to the favorable environmental conditions for the specific period of time which positively affected growth of the plant and hence maximum number of leaves was observed. Our results are in agreement with the previous findings of [13], they showed that early sowing favored bulb, leaf and root growth and gave maximum yield. In the same way, the lower number of leaves at later planting dates greatly compared with the results of Attar [9], who reported that later planting resulted in a reduction in the number of leaves, gross yield and net yield.

Different row spacing also showed significant influence on the number of leaves of onion. Highest numbers of leaves (10.18) were obtained in plants with $30 \mathrm{~cm}$ row spacing which was statistically different from the rest of treatments, followed by plants having 25 and $20 \mathrm{~cm}$ spacing with 9.00 and 8.07 leaves, respectively. While the plants row spaced at $15 \mathrm{~cm}$ gave the least number of leaves (7.29). It might be because of the competition among the plants to get the required food for their growth due to the closer spacing. Weerasinghe [14] also showed the result that rising plant competition significantly reduced seedling leaf number. Mari [15] Rizk [16] also reported that lowering population densities resulted in a higher number of leaves plant ${ }^{-}$ 1. Likewise, Singh and Schan [17] stated that with maximum spacing higher number of leaves can be obtained.

The interaction between the transplanting dates and row spacing was also found significant. Highest numbers of leaves (12.00) were noted in $15^{\text {th }}$ December, row spaced at $30 \mathrm{~cm}$ followed by $31^{\text {st }}$ December with $30 \mathrm{~cm}$ row spacing and $15^{\text {th }}$ December with $25 \mathrm{~cm}$ row spacing having 10.67 and 10.18 leaves, respectively. The least response was reported in row spacing of 15 $\mathrm{cm}$ transplanted at $15^{\text {th }}$ January (6.00).

\section{Leaf width (cm)}

The statistical analysis of data showed that transplanting dates and row spacing, significantly influenced leaf width of onion, whereas the interaction between transplanting dates and row spacing was found non-significant (Table 1). The data showed that $15^{\text {th }}$ December transplantation produced higher leaf width $(1.42 \mathrm{~cm})$ than that of $31^{\text {st }}$ December and $15^{\text {th }}$ January having 1.37 and $1.15 \mathrm{~cm}$ leaf width, respectively. The reason for such a result might be due to the favorable environmental conditions for the specific period of time which positively affected growth of the plant and hence maximum leaf width was recorded. The same results were shown by Hussain and Islam [18] who reported that early planting produced larger number of leaves plant ${ }^{-1}$ and leaf width which decreased gradually with delayed planting. 
Different row spacing also showed significant influence on leaf width of onion. Higher leaf width $(1.41 \mathrm{~cm})$ was obtained in plants with $30 \mathrm{~cm}$ row spacing which was statistically different from the rest of treatments, followed by plants having 25 and $20 \mathrm{~cm}$ spacing with 1.35 and $1.28 \mathrm{~cm}$ widths, respectively. While the plants row spaced at $15 \mathrm{~cm}$ gave the least leaf width $(1.21 \mathrm{~cm})$. Availability of more sunlight due to wider spacing might have enhanced the number of leaves plant ${ }^{-1}$ and leaf width. Similar results were shown by Singh and Sachan [17], Naruka and Singh [19] in garlic and Shanti and Balakrishnan [20] in aggregatum onion. Generally high planting density results in less availability of soil nutrients, light and water etc, might be due to this the leaf did not attain their respective size.

\section{Plant height (cm)}

The data about the height of plants gave significant results for transplanting dates and different row spacing (Table 1). Plants transplanted at $15^{\text {th }}$ December gave the tallest plants $(47.58 \mathrm{~cm})$, which significantly varies from the rest of treatments, followed by $31^{\text {st }}$ December transplantation $(42.58 \mathrm{~cm})$. While the minimum plant height $(35.42 \mathrm{~cm})$ was recorded in seedlings transplanted on $15^{\text {th }}$ January. The reason for such a result might be due to the favorable environmental conditions for the specific period of time which positively affected growth of the plant and hence maximum plant height was recorded. The same results were shown by Rahman [21] that onion transplanted in December had highest number of leaves (8.6), taller plant up to $(50 \mathrm{~cm})$ and highest yield $9.6 \mathrm{t} \mathrm{ha}^{-1}$ while in case of January transplant lowest yield of $1.3 \mathrm{t} \mathrm{ha}^{-1}$ was recorded. Plant height has strong positive relation with leaf number plant $^{-1}$; bulb yield and bulb diameter plant $^{-1}$. Onion yield showed significant positive relation with plant height and bulb yield plant ${ }^{-1}$ [22].

Different row spacing significantly affected the plant height in onion production. Maximum plant height $(47.00 \mathrm{~cm})$ was recorded in the plants spaced $30 \mathrm{~cm}$, followed by the plants spaced by 25 and 20 $\mathrm{cm}$ with 43.67 and $39.78 \mathrm{~cm}$ heights, respectively, while the minimum height $(37.00 \mathrm{~cm})$ was reported in the plants with $15 \mathrm{~cm}$ row spacing. Likewise, Khan [23] also stated that due to more increased competition amongst the lowest plant spacing, it gave least response for plant height in onion. Our results are in agreement with the previous findings of Khan [10] who also reported that wider plant spacing produced higher plant size, this may due to wider spaces and effective utilization of sun light during photosynthesis.

Interaction between transplanting dates and row spacing was significant. Maximum plant height $(53.00 \mathrm{~cm})$ was recorded in onion seedling transplanted on $15^{\text {th }}$ December with $30 \mathrm{~cm}$ plant spacing. While lower plant height $(33.00 \mathrm{~cm})$ was obtained in seedling transplanted on $15^{\text {th }}$ January row spaced at $15 \mathrm{~cm}$.

\section{Bulb diameter $(\mathbf{c m})$}

The mean data table clearly showed that transplanting dates, row spacing significantly affected bulb diameter where as a non-significant variation was observed in interaction between transplanting dates and row spacing (Table 1). More bulb diameter $(6.06 \mathrm{~cm})$ was recorded in seedling transplanted on $15^{\text {th }}$ December, whereas, $31^{\text {st }}$ December produced smaller bulbs $(5.56 \mathrm{~cm})$. Seedlings that were transplanted on $15^{\text {th }}$ December resulted in maximum bulb diameter. This may be due to the favorable environmental conditions for the specific period of time which positively affected growth of the plant and hence maximum bulb diameter was 
observed. Our results are in agreement with findings of Lisbao [24] and Nes [25] who found that delay in sowing lead to small bulb size.

Different row spacing showed significant variations and the maximum spacing (30 $\mathrm{cm})$ was superior to all the other spacing, where higher bulb diameter $(6.58 \mathrm{~cm})$ was obtained, followed by $25 \mathrm{~cm}$ spaced plants, giving $(6.04 \mathrm{~cm})$ bulb diameter. While seedling row spaced at $15 \mathrm{~cm}$ give the lowest bulb diameter $(4.01 \mathrm{~cm})$. Khan [10] also stated that wider plant spacing increases the bulb diameter in onion. As the plant spacing was reduced the bulb diameter also reduced. The reason might be due to the high competition of bulbs for the nutrients, water and shade with low plant spacing and vice versa. Our results get support from the previous work done by Balraj [26] who also stated that increasing the plant spacing resulted in an increased bulb diameter of onion.

Table 1. No. of leaves plant ${ }^{-1}$, leaf width $(\mathrm{cm})$, plant height $(\mathrm{cm})$, bulb diameter $(\mathrm{cm})$

\begin{tabular}{lcccc}
\hline $\begin{array}{c}\text { No. of leaves } \\
\text { Plant }{ }^{-1}\end{array}$ & $\begin{array}{c}\text { Leaf width } \\
(\mathbf{c m})\end{array}$ & $\begin{array}{c}\text { Plant height } \\
(\mathbf{c m})\end{array}$ & $\begin{array}{c}\text { Bulb Diameter } \\
(\mathbf{c m})\end{array}$ \\
\hline \multicolumn{2}{l}{ Transplanting Dates } & & & \\
\hline 15th Dec & $9.94 \mathrm{a}$ & $1.42 \mathrm{a}$ & $47.58 \mathrm{a}$ & $6.06 \mathrm{a}$ \\
31st Dec & $9.16 \mathrm{a}$ & $1.37 \mathrm{a}$ & $42.58 \mathrm{~b}$ & $5.56 \mathrm{~b}$ \\
15th Jan & $6.80 \mathrm{~b}$ & $1.15 \mathrm{~b}$ & $35.42 \mathrm{c}$ & $4.96 \mathrm{c}$ \\
\hline LSD (0.05) & 1.58 & 0.07 & 2.64 & 0.31 \\
\hline Row Spacing & & & & \\
\hline 15cm & $7.29 \mathrm{~d}$ & $1.21 \mathrm{~d}$ & $37.00 \mathrm{~d}$ & $4.01 \mathrm{~d}$ \\
20cm & $8.07 \mathrm{c}$ & $1.28 \mathrm{c}$ & $39.78 \mathrm{c}$ & $5.47 \mathrm{c}$ \\
25cm & $9.00 \mathrm{~b}$ & $1.35 \mathrm{~b}$ & $43.67 \mathrm{~b}$ & $6.04 \mathrm{~b}$ \\
30cm & $10.18 \mathrm{a}$ & $1.41 \mathrm{a}$ & $47.00 \mathrm{a}$ & $6.58 \mathrm{a}$ \\
\hline LSD (0.05) & 0.529 & 0.041 & 1.264 & 0.233 \\
\hline
\end{tabular}

Means followed by different letter(s) are significantly different at 5\% level of significance used LSD test.

Average bulb weight (g)

The data regarding bulb weight ( $g$ ) of onion is given in (Table 2). The mean data table clearly showed that transplanting dates, row spacing significantly affected bulb weight where as a non-significant variation was observed in the interaction between transplanting dates and row spacing.

The data showed that $15^{\text {th }}$ December transplantation leads to much heavier bulb (79.70 g) as compared to $31^{\text {st }}$ December and $15^{\text {th }}$ January, producing bulbs of 72.62 and $69.14 \mathrm{~g}$, respectively. The reason for such a result might be due to the favorable environmental conditions for the specific period of time which positively affected growth of the plant and hence maximum average bulb weight was observed. Our results are supported the findings of Singh and Singh [13] and Mingochi and Mpanda [27] they found that early dates of sowing gave maximum bulb weight which was reduced by late sowing.

The results once again showed that the maximum row spacing $(30 \mathrm{~cm})$ was superior to all the other spacing, as it produced much heavier bulb weight as compared to the other row spacing. Significantly maximum average bulb weight (91.59 g) was obtained in the maximum row spacing $(30 \mathrm{~cm})$, followed by $25 \mathrm{~cm}$ row spacing with $(79.76$ g) weighed bulbs. While the closest row spacing $(15 \mathrm{~cm})$ gave minimum bulb weight $(54.50 \mathrm{~g})$. Wider row spacing produced 
heavier bulbs and this might be due to effective utilization of environmental resources due to little competition as compared to the closely spaced plants. Similar results were showed by Balraj [26] Khan [10, 23] who stated that wider plant spacing in onion, resulted in heavier bulb production.

\section{Number of bulbs $\mathrm{kg}^{-1}$}

The result showed that number of bulbs $\mathrm{kg}^{-1}$ of onion cultivar "Swat 1" was significantly affected by transplanting dates and different row spacing while the interaction between transplanting dates and row spacing was non-significant (Table 2). It was noted that $15^{\text {th }}$ January transplanted seedlings produced a comparatively higher number of bulbs $\left(14.83 \mathrm{~kg}^{-1}\right)$ than $31^{\text {st }}$ December and $15^{\text {th }}$ December having 14.25 and 13.08 numbers of bulbs $\mathrm{kg}^{-1}$, respectively. Seedlings that were transplanted on $15^{\text {th }}$ December resulted in less number of bulbs $\mathrm{kg}^{-1}$. This may be due to the favorable environmental conditions for the specific period of time which positively affected growth of the plant. The results were in conformity with Nes [25] who reported that late sowing reduced bulb size and Khokhar [28] Mingochi and Mpanda [27] also reported that early sowing increase bulbs weight.

Different row spacing also significantly affected the number of bulbs $\mathrm{kg}^{-1}$. The results showed that maximum number of bulbs $\left(18.22 \mathrm{~kg}^{-1}\right)$ was recorded in the plants with the closest row spacing of $15 \mathrm{~cm}$, followed by the row spacing of 20 and 25 $\mathrm{cm}$ giving an average number of bulbs 14.44 and $12.56 \mathrm{~kg}^{-1}$, respectively. The minimum number of bulbs $\left(11.00 \mathrm{~kg}^{-1}\right)$ was recorded with the maximum row spacing $30 \mathrm{~cm}$. The reason, for such a result might be that with wider row spacing the number of seedling bulbs were reduced, thus causing a reduction in yield and vice versa. Similar results were quoted by Kumar [29] 1998 Rashid and Rashid [30] who found that onion bulb size and weight increases with increasing row spacing but reduced total bulb yield. The yield decreased with increasing the row spacing and the number of marketable bulbs reduced.

\section{Total yield ha-1 (tons)}

The data in Table 2 showed that yield $\mathrm{t} \mathrm{ha}^{-1}$ was statistically affected by transplanting dates and row spacing, while their interactions were non-significant. The data showed that $15^{\text {th }}$ December transplantation produced more onion yield $\left(28.64 \mathrm{t} \mathrm{ha}^{-1}\right)$ than $31^{\text {st }}$ December and $15^{\text {th }}$ January with 26.44 and 25.21 yield $\mathrm{t} \mathrm{ha}^{-1}$, respectively. Seedlings that were transplanted on $15^{\text {th }}$ December resulted in maximum yield $\mathrm{tha}^{-1}$. This may be due to the favorable environmental conditions for the specific period of time which positively affected growth of the plant and hence maximum yield $t \mathrm{ha}^{-1}$ was recorded. The results were in conformity with Brewster [31] Lisbao [24] Nes [25] Guerra and Tomer [32] who stated that delayed sowing date shortened the cultural cycle of the onion cultivars but resulted in small bulb size and lowest yield. Different row spacing significantly affected the yield $\mathrm{t} \mathrm{ha}^{-1}$. The lowest bulb yield was recorded for the maximum row spacing of $30 \mathrm{~cm}$ with a yield $\left(23.03 \mathrm{t} \mathrm{ha}^{-1}\right)$ while the highest yield $\left(29.29 \mathrm{~kg} \mathrm{ha}^{-1}\right)$ was recorded in row spacing of $20 \mathrm{~cm}$. Generally high planting density results in less availability of soil nutrients, light and water etc. due to this the bulbs did not attain their respective size. Our results also support the findings of Rashid and Rashid [30] Kumar [29] Resendle [33] they found that onion bulb size and weight increases with increasing inter and intra row spacing while decreasing the plant spacing will ultimately increase the total yield in onion. The present results also agreed with Stoffella [34] who reported that $\%$ age (weight) of small bulbs increased as in-row spacing decreased i.e. as plant density increased. Similarly, Cardoso and 
Costa [35] found that higher planting density results in smaller bulb's size; and yield of small bulbs was highest at the highest planting density of 140 plants $4 \mathrm{~m}^{-2}$ Rumpel [36] and Rizk [16] observed that the highest sowing rate (planting density) produced a noticeably higher yield of good quality bulbs than the lower sowing rate. May [37] found similar results that bulb size decreased as plant population increased from 60 to 108 plants $\mathrm{m}^{-2}$. Generally, higher onion yield is obtained with increasing plant population (plants $\mathrm{ha}^{-1}$ ) Bleasdale [38] Brewster and Salter [39] Kelbert [40] and McGeary [41]. The results showed that by increasing the spacing the yield also declined.

Table 2. Average bulb weight (g), number of bulbs kg-1, total yield ha-1 (tons)

\begin{tabular}{lccc}
\hline & $\begin{array}{c}\text { Average Bulb } \\
\text { weight }(\mathbf{g})\end{array}$ & $\begin{array}{c}\text { Number of } \\
\text { bulbs kg-1 }\end{array}$ & $\begin{array}{c}\text { Total Yield } \\
\text { ha }^{-1} \text { (tons) }\end{array}$ \\
\hline \multicolumn{2}{l}{ Transplanting Dates } & & \\
\hline 15th Dec & $79.70 \mathrm{a}$ & $13.08 \mathrm{~b}$ & $28.64 \mathrm{a}$ \\
31st Dec & $72.62 \mathrm{~b}$ & $14.25 \mathrm{a}$ & $26.44 \mathrm{~b}$ \\
15th Jan & $69.14 \mathrm{~b}$ & $14.83 \mathrm{a}$ & $25.21 \mathrm{~b}$ \\
\hline LSD (0.05) & 6.54 & 0.94 & 1.91 \\
\hline Row spacing & & & \\
\hline 15cm & $54.50 \mathrm{~d}$ & $18.22 \mathrm{a}$ & $27.63 \mathrm{~b}$ \\
20cm & $69.43 \mathrm{c}$ & $14.44 \mathrm{~b}$ & $29.29 \mathrm{a}$ \\
25cm & $79.76 \mathrm{~b}$ & $12.56 \mathrm{c}$ & $27.10 \mathrm{~b}$ \\
30cm & $91.59 \mathrm{a}$ & $11.00 \mathrm{~d}$ & $23.03 \mathrm{c}$ \\
\hline LSD (0.05) & 5.225 & 0.904 & 1.570 \\
\hline
\end{tabular}

Means followed by different letter(s) are significantly different at 5\% level of significance used LSD test.

\section{Conclusion and recommendations}

In case of population densities, the plants with row spacing of $20 \mathrm{~cm}$ resulted in maximum yield of onion. Seedling transplanted on $15^{\text {th }}$ December showed best results regarding number of leaves, plant height, leaf width, bulb diameter, average weight of bulb and yield $\mathrm{t} \mathrm{ha} \mathrm{h}^{-1}$. Since best yield was observed at row spacing $20 \mathrm{~cm}$ with a transplanting date of $15^{\text {th }}$ December, therefore recommended for onion production under the agro climatic condition of Malakand. It is recommended that this research be further expended using $5,10,15$ and $20 \mathrm{~cm}$ row to row spacing and $15^{\text {th }}$ Nov, $1^{\text {st }}$ Dec and $15^{\text {th }}$ Dec transplanting dates.

\section{Authors' contributions}

Conceived and designed the experiments: A Rab \& H Muhammad, Performed the experiments: M Ali, Analyzed the data: S Hayat \& H Ahmad, Contributed reagents/ materials/ analysis tools: J Ali, K Wali \& W Ahmad, Wrote the paper: M Ali \& A Rashid.

\section{Acknowledgements}

The research was facilitated by Agriculture Extension Department, Dargai Malakand Division, Pakistan. I am personally very much obliged to Dr. Abdur Rab and Dr. Haji Muhammad for providing me space and advisory assistance. At the same time, I am thankful to all of my colleagues whose help enabled me and gave me strength to write this manuscript.

\section{References}

1. Khoso AW (1988). Bulbous vegetable. Growing vegetable in Sindh. Mohammad Ismail Khoso Publication, Tandojam. Ahmed Brothers Printers, Nizamabad, Karachi. 134.

2. Ware GW \& McCollum JP (1968). Onions Producing veg crops. The Interstate 
Printers and Publishers, Inc. Danville, IIIinois. 607.

3. Denisen EL (1958). Principles of Horticulture. The Macmillan Publication Company, New York. Printed in the U.S.A. Pp. 509.

4. Thompson HC \& Kelly WC (1982). Bulb crops. Veg Crops. Tata McGrew-ill Publishing Company Limited, New York. Reprinted at Pak Printing Works, Lahore. 611.

5. Mondal MF, Brewster JL, Morris GEL \& Butter HA (1986). Bulb development in onion (Allium cepa L.) effect of plant density and sowing date in field conditions. Ann Bot 58: 187-195.

6. Izquierdo JA, Maeso CR \& Villanmil J (1981). Effects of sowing and transplanting dates on yields of valenciana type onion. Investigations Agronomics 2: 34-37.

7. Bhattarai SP, Adhikan B \& Amatya LK (1995). Varietal and time of planting research on normal season onion at Lumle and off station sites conducted during 1992/93 season. Working paper Lumble Regional Agric Res 95: 49.

8. Mondal MF \& Hussain A (1980). Effect of time of planting of onion bulbs on the yield and quality of seeds. Bangladesh $J$. Agric 5: 131-134.

9. Attar S, Korla BN \& Singh A (1991). Effect of transplanting dates and varieties on number of leaves and yield on onion (Allium cepa L.). Veg. Sci. 18(1):24-28.

10. Khan MK, Hasan MA, Miah M, Alam M \& Masum AS (2003). Effect of plant spacing on the growth and yield of different cultivars of onion. Pak J Biol Sci 6(18): 1582-1585.

11. Brewster JL (2008). Onions and other Vegetables Alliums, $2^{\text {nd }}$ ed. $C A B$ International, Wallingford. Pp. 85-150.

12. Geremew A, Teshome A, Kasaye $\mathrm{T} \&$ Amenti C (2010). Effect of intra-row spacing on yield of three onion (Allium cepa L.) varieties at Adami Tulu Agricultural Research center (mid rift valley of Ethiopia). J Hort Forestry 2(1): 007-011.

13. Singh DP \& Singh RP (1975). Studies on the effect of time of sowing and age of seedling on growth and yield of onion (Allium cepa L.) Ind J Hort 31(1): 69-73.

14. Weerasinghe SS, Fordhan R, Babik I \& Rumpel J (1994). The effect of plant density on onion established from multiseeded transplants. $7^{\text {th }}$ Inter. Symp. on timing field production of vegetables, Skierniewice, Poland. Acta Hort. 371: 97104.

15. Mari JA, Mondal L, Fuentes P, Cristo M, Martinez J \& Donate M (1997). Effect of transplanting density of the cultivar Yellow Grancx Hybrid of onion on yield and bulb size. Centro-Agricola 24(1): 5055.

16. Rizk FA (1997). Productivity of onion plant (Allium cepa L.) as affected by method of planting and NPK application. Egypt J Hort 24(2): 219-228.

17. Singh SR \& Sacchan BP (1998). Response of different bulb size and spacing combinations on seed yield and yield attributing traits of onion (Allium cepa L.) Haryana J Hort Sci 21(1): 56-58.

18. Hussain AKMA \& Islam J (1994). Status of Allium Production in Bangladesh. Acta Hort 358: 33-36.

19. Naruka I \&, Singh B (2002). Interactive effect of row spacing and cultivars on the yield and yield attributes of garlic (Allium sativum L.) Haryana J Hort Sci 31 (3 \& 4): 262-264.

20. Shanti K \& Balakrishnan R (1989). Effect of nitrogen, spacing and maleic hydrazide on yield, nutrient uptake, quality and storage of MDU-1 onion. Indian J Hort 16: 490-494.

21. Rahman MA, Saha SR, Salam MA, Masum ASMH \& Chowdhury SS (2002). Correlation and path coefficient Analysis in onion (Allium cepa L.) J Biol Sci 2(8): 533-534.

22. Vadivel B, Muthukrishnan CR \& Irulappan I (1981). Association of characters between yields and yields 
components in Aggregatum onion (Allium cepa L.). Sputh Indian hort 29: 227-228.

23. Khan HB, Iqbal M, Ghafoor A \& Waseem K (2002). Effect of various plant spacing and different nitrogen levels on the growth and yield of onion (Allium cepa.L). J Biol Sci 2(8): 545-547.

24. Lisbao RS, Fornasier JB, Lgue T \& Cury AP (1985). Evaluation of onion cultivars at different sowing dates. Hort Absts 44(1): 441-40.

25. Nes A (1985). Effect of sowing dates and day length before transplanting in onion (Allium cepa L.). Hort Abst 55(12): 9465.

26. Balraj S, Sharma RS \& Kumar Y (1998). Effect of bulb spacing and nitrogen levels on growth and seed yield of onion (Allium cepa L.). Seed Res., Jaipur, India, 3(1): 180-182.

27. Mingochi DS \& Mpanda EK (1992). Evaluation of some short day onion cultivars in Taiwan. Onion Newsletter for the Tropics 4: 45-48.

28. Khokhar KM, Kaska N, Hussain SI, Qureshi KM \& Mehmood T (1990). Effect of different sowing dates, direct seedling and transplanting of seedlings on maturation, bulb weight and yield in onion (Allium cepa L.) cultivars. Ind J Agric Sci 60(10): 668-671.

29. Kumar H, Singh JV, kumar A, Singh M \& Kumar A (1998). Studies on the effect of spacing on growth and yield of onion (Allium cepa L.) cv. Patna Red. Indian J of Agric Res. 32(2): 134-138.

30. Rashid MA \& Rashid MM (1978). The effect of spacing on the yield of onion. Hort Abst 48(6): 481-486.

31. Brewster JL (1994). Onions and other Vegetable Alliums. Hort. Res. Intern., Wellesbourne, CAB International. 236

32. Guerra M (1987). The effect of sowing dates on plant density on the yield of three onion cultivars. Hort Abst 58(6): 3361.

33. Resende GMD, Costa ND \& Souza Dias R (de) C (1999). Population densities for onion production in the Sao Francisco valley. Comunicado Tecnico Centro de Pesquisa Agropecuaria do Tropic SemiArid. 81:4.

34. Stoffella PJ (1996). Planting arrangement and density of transplants influence sweet Spanish onion yields and bulb size. Hort Sci 31(7): 1129-1130.

35. Cardoso AII \& Costa OP (1999). Production of onion bulb sets in tyro foam trays. Scientia- Agricola 56(4): 969 974.

36. Rumpel J, Felczynski K, Stoffella PJ, Cantliffe DJ \& Donialo G (2000). Effect of plant density on yield and bulb size of direct sown onions. $8^{\text {th }}$ Inter. Symp. On timing of Field prod. In vege. Crops, Bari, Italy. Acta Hort 533: 179-185.

37. May A, Filho ABC, Porto DRQ, Vargas PF \& Barbosa JC (2007). Plant density and nitrogen and potassium fertilization rates on yield of onion hybrids. Hort Brasileira 25: 53-59.

38. Bleasdale JKA (1966). The effects of plant spacing on the yield of bulb onions (Allium cepa L.) grown from seed. J Hort Sci 41: 145-153.

39. Brewster JL \& Salter PJ (1980). The effect of plant spacing on the yield and bolting of two cultivars of over wintering bulb onions. J Hort Sci 55: 97-102.

40. Kelbert DGA \& Burgis DS (1962). Adaptable varieties, herbicides, and plant spacing for bulb onions on sandy land. Proc Fla State Hort Soc 75: 153-156.

41. McGeary DJ (1985). The effects of plant density on shape, size, uniformity, soluble solid content, and yields of onions suitable for pickling. J Hort Sci 60: 8387. 